\title{
Impact of Social Network Sites in the Life of University Students: A Case Study of Pokhara University, Nepal
}

\author{
Deepanjal Shrestha ${ }^{1}$, Neesha Rajkarnikar ${ }^{2}$, Deepmala Shrestha ${ }^{3}$, Rojana Dhakal ${ }^{4}$, \\ and Seung Ryul Jeong ${ }^{5}$
}

\author{
${ }^{1}$ PhD Research Scholar, School of Computer Science and Technology, Nanjing University of Aeronautics \& Astronautics, \\ Nanjing, China. \\ ${ }^{2} \mathrm{PhD}$ Research Scholar, School of New Energy Science and Engineering Pukou, Nanjing, China \\ ${ }^{3}$ Assistant Professor, School of Business, Pokhara University Pokhara, Nepal. \\ ${ }^{4}$ Assistant Professor, School of Nursing, Pokhara University Pokhara, Nepal \\ ${ }^{5}$ Professor, Graduate School of Business IT, Kookmin University, Seoul, South Korea \\ Correspondence should be addressed to Deepanjal Shrestha; deepanjal@pusob.edu.np
}

Copyright @ 2021 Deepanjal et al. This is an open access article distributed under the Creative Commons Attribution License, which permits unrestricted use, distribution, and reproduction in any medium, provided the original work is properly cited.

\begin{abstract}
This work analyses the impact of social network sites on the life of a university student in terms of intensity of use, personal life satisfaction, social trust, social expression and physical health. Study is based on close end survey design and consists of one hundred and fifty-four (154) respondents of four constituent campuses of Pokhara University, Nepal. The study uses both descriptive and inferential statistical methods to analyze data, draw conclusions and forward recommendations of the study. Chi-square test is also performed on the identified variables under investigation to calculate association among them. The work summarizes both the positive as well as negative aspects of using social network sites on the life university students that helps to build an understanding of role of technology in their life. Further, this study can serve as a base in identifying the socio-psychological aspects of technology of human life. For universities of under developed countries like Nepal, this can be a vital study in understanding technology and its application in academia.
\end{abstract}

KEYWORDS- Social networking sites, Intensity of use, Physical health, Personal life satisfaction, Social trust, Social learning, Social expression.

\section{INTRODUCTION}

The rapid growth of high speed internet, web enabled application and the mobile technology has changed the way we access and consume information. Access to enormous information is just a click away from us. These technologies are creating a massive flux of information at a speed undefined [1]. The production, consumption and distribution of information due to varied technologies like social media, streaming media, blogs, Peer to Peer (P2P) technology, etc., and the interconnection of almost every computing device has forced us to redefine our social and cultural pattern, privacy and legacy issues. [1]

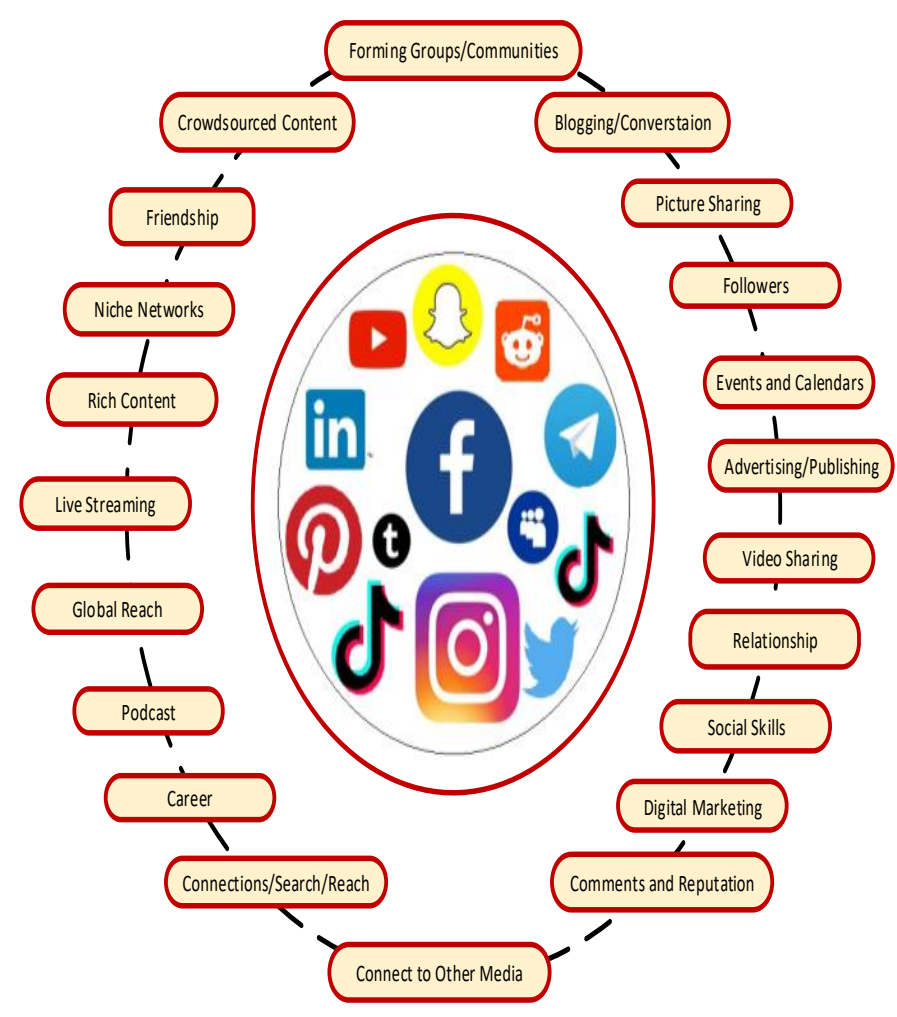

Fig. 1: Social network site attributes and usage [2][3][15]

People using social network sites can frequently exchange dialogue, collaborate among themselves, get engaged in conversation, or express themselves frequently through text message, voice massages, images or videos clips. Social network sites (SNSs) make it is easy and accessible for friends and family members to communicate, if anyone has access to internet and technology. SNS such as Facebook, Wechat, Skype, Twitter and Whatsapp etc., has become the habit of users and many of them have integrated these sites as a part of their daily routine [2]. The users swarm around these sites to socialize with their family, friends and 
acquaintances, to share their interest and information, and to follow and get followed [3]. Figure 1 above shows the different dimensions of Social network site with their characteristic and usage. People consume a lot of time on these sites uploading or downloading pictures, video clips and getting information on current issues, breaking news, keep up with friends and colleagues, and contribute to online debates including research and development activities [4]. Das \& Sahoo in their research paper stated that social site has become a habit for young people especially the learning students and they are accustomed to check their updates and profiles every now and then (2014). They also state that this habit is so intense in few youngsters that it can lead to disorder like "FAD (Facebook Addiction Disorder)" [5]. Lenhart \& Madden further add that adolescents and college students primarily use these sites to stay in touch with friends they see often and those whom they see rarely [6]. Pempek et al research also showed that regardless of how busy college students were, social networks (Facebook in particular) was a part of their daily life [7]. Many other studies had reached similar conclusions and drawn attention to the frequent use of social networks sites by young people and college students. It is further of interest that growing popularity, use and practice of social site by students can make a real impact on different aspects of their life which is an important area to study.

\section{A. Statement of Problem}

Students today are networked with each other using technology as much as, if not more than, face-to-face communication [8][9][10]. With so many young people spending significant amount of their time on computer mediated communication channels, it comes to mind that they must be meeting personal and social needs from these technologies. This demands an introspection of their personal and social behavior on Social Network Sites [11][2]. The recent time has seen a steep rise in the usage of social sites in a level that resembles like an addiction. Researches have shown that students run a social networking site on the background of their PC while studying or doing homework and check in their update every now and then [12][13]. A survey conducted among 1000 people across United States finds 56 percent users check Facebook at least once a day, people under 25 years are more likely to lose sleep keeping an eye on their friends post, iinterestingly 17 percent would read a message on Facebook during sex and 63 percent while in the toilet [14]. The use of SNS is seen as a tool for intellectual and open discussions, community group formations and discussion board [15]. According to the above raised scenarios it has become important to introspect the impact of SNS on the university students. As the intensity of use of SNS is growing as a new tool for social expression, its impact on student's well-being, personal life satisfaction, academic learning and physical health become an important part of study.

\section{B. Hypothesis}

This study has formulated the following hypothesis:

H1: There is no association between the SNS intensity level and the physical health of university students.

$\mathrm{H} 2$ : There is no association between the SNS intensity level and the life satisfaction of university students.

H3: There is no association between the SNS intensity level and the social trust of university students.
H4: There is no association between the SNS intensity level and the civic participation of university students.

H5: There is no association between the SNS intensity level and the political participation of university students.

\section{LITERATURE REVIEW}

Internationally social network sites are increasingly becoming an international phenomenon in terms of usage and sharing of information. The computer literates are taking social network sites as a part of living and their social norms. [16]. Social site have become immensely popular among the teenagers and young adults who have adopted this technology as a way of life to connect with their friends, share information, showcase their social lives and reinvent their personalities [17].The increased use of technology, internet and communication technology, Social network sites has become a routine activity that is done primarily online using various applications like MySpace, Twitter, Face book, QQ, Bebo, Friendster, and Xanga [18]. Survey conducted in US with teen age respondents depicted that approximately $90 \%$ of teens have access to internet and about $75 \%$ of these teens use Internet more than once per day [19]. Another inference that was drawn from the study showcased that approximately $50 \%$ of all the teens who have access to Internet are also Social network site members using these sites to plan for hangouts, parties, and other ways of socializing [19]. Technology and internet are powerful sources that can influence students and their educational performance both positively or adversely. Shah et al. in his study concluded that internet has effect on the students and the impact is determined by the way internet is used. If internet use is for recreational activities it has drastic impact and if internet is used for looking for information, it greatly benefits the overall development of an individual positively [21]. Kist also studied internet in academia and found that it is advantageous to teachers and students if it is used as a tool to create knowledge and distribute accordingly [11]. Kirschnera found out a very interesting fact, which stated that Social site technologies have become so advanced that they are capable for running in the background and this has forced individual to be in constantly in touch creating curiosity and continuous engagement with application running in background while individuals are executing their tasks [14]. The increased use and popularity rate of Social network sites now calls for the parents and teachers to monitor its use and it has created a need for scholars and researchers to understand and study this phenomenon [23] [24]. Recent trends show that social media usage has increased as of January 2021, one of the most well-known social media sites is Facebook [25]. This site currently boasts 2.7 billion monthly active users, and over $50 \%$ of active users $\log$ on to the site every day [25] as shown in figure 2 . Further, more than 1.3 billion monthly active users access the site through a mobile device [25]. According to study done by Eldon [4], 51.2\% of users are male, whereas $48.8 \%$ are female in age groups of ages of 13 and 17 with $20.6 \%$ of users, $25.8 \%$ are between the ages of 18 and 25 ; $26.1 \%$ are between the ages of $26-34$; and $27.5 \%$ are over the age of 35 [4]. In 2011, some scholars applied gratification and usage approach to discover the intent of users in general. They found that users are mainly motivated with a desire to update status to get attention, express, share information and for relaxing, companionship, entertainment, and social interaction [26]. Smock et al. also concluded 
similar finding that, social interaction was the main motive to use Facebook and chat feature [26].

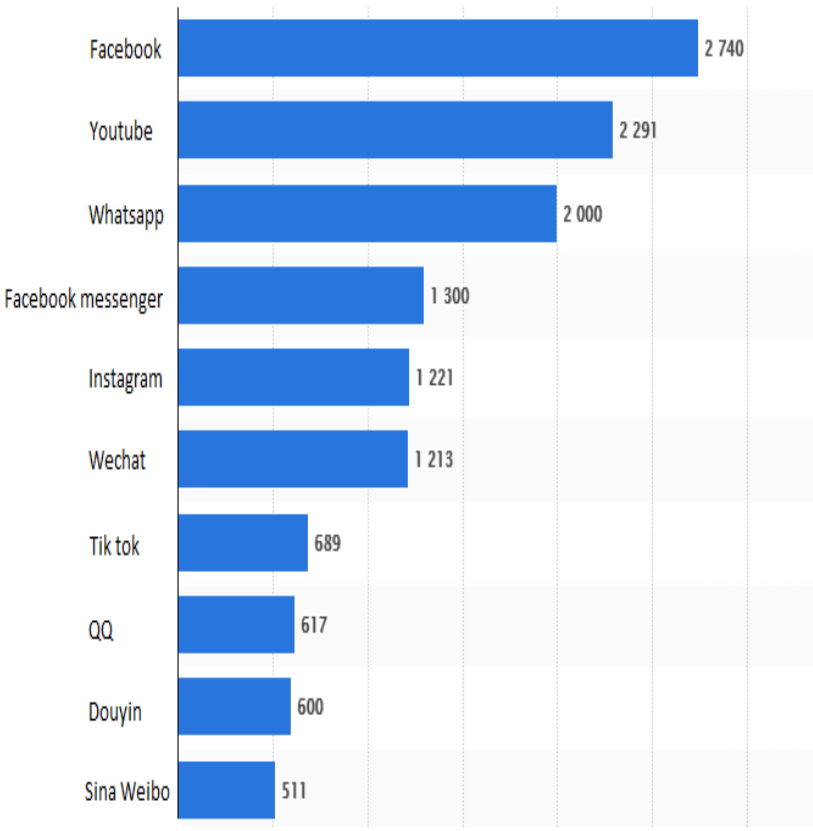

Fig. 2: Top 10 popular social networks data of January 2021, ranked by number of active users (in millions) [23]

\section{RESEARCH METHODOLOGY}

The study is cased based, socio-psychological and sociotechnical research that understands the social impact of this technological innovation on Pokhara university students. The parameters for the study are Social Network Sites, wallpostings, expressions, learning skill, physical effect, personal life satisfaction, social trust and the effect of these on one another. Both qualitative and quantitative data are collected for this study, hence primary and secondary data sources are used in the study. Primary data were collected from field observation (four schools of PU) and questionnaire schedule whereas for the secondary source, information were collected from the published and unpublished dissertation, journals, books, reports from different seminars/workshops. The population for this study is selected from the total number of students (N-population size $=1513$ for 2018/2019) academic session, based on the data obtained from the administration offices of Pokhara University. The sample size is determined, $\mathrm{n}$ with 0.075 degree of error.

\section{Formula:}

According to Cochran's sample size calculation method, $\mathrm{n}=\mathrm{n}_{0} \times \mathrm{N} /\left(\mathrm{n}_{0}+\mathrm{N}-1\right)$ and $\mathrm{n}_{0}=\mathrm{t}^{2} \mathrm{pq} / \mathrm{d}^{2}$ where,

$\mathrm{N}=$ total population size

$\mathrm{n}_{0}=$ the desired sample size

$\mathrm{t}=$ the standard normal deviate set at 1.96 for 95 percent confidence level

$\mathrm{p}=$ estimated proportion of an attribute that is present in the population $=0.5$

$\mathrm{q}=1-\mathrm{p}=1-0.5=0.5$

$\mathrm{d}=$ Acceptable margin of error for proportion being estimated $=0.075$

Now, using the formula:

$$
\mathrm{n}_{0}=\mathrm{t}^{2} \mathrm{pq} / \mathrm{d}^{2}
$$

$$
\begin{aligned}
& =(1.96)^{2} \times(0.5 \times 0.5) /(0.075)^{2} \\
& =170.74 \\
\mathrm{n} & =\mathrm{n}_{0} \mathrm{xN} /\left(\mathrm{n}_{0}+\mathrm{N}-1\right) \\
& =170.74 \times 1513 /(170.74+1513-1) \\
& =153.51 \approx 154
\end{aligned}
$$$$
\text { Again, }
$$

\section{CONCEPTUAL FRAMEWORK}

The literature has revealed several commonly observed antecedents of impact of SNS on university students. This study examines previously identified antecedents and outcomes on the field of SNS that appear most applicable in the Nepalese context more specifically in the present setting i.e. in the setting of Pokhara University, Kaski. The overall conceptual model guiding the study is shown in figure 3 . As seen in the figure demography, physical health, intensity of use, personal life satisfaction and social trust, and social expressions are the primary domain of this study. Demography consist of 9 variables, intensity of use consist of 4 variables, personal life satisfaction and social trust consist of 7 variables, social expression consist of 7 variables and physical health consist of 2 variables.

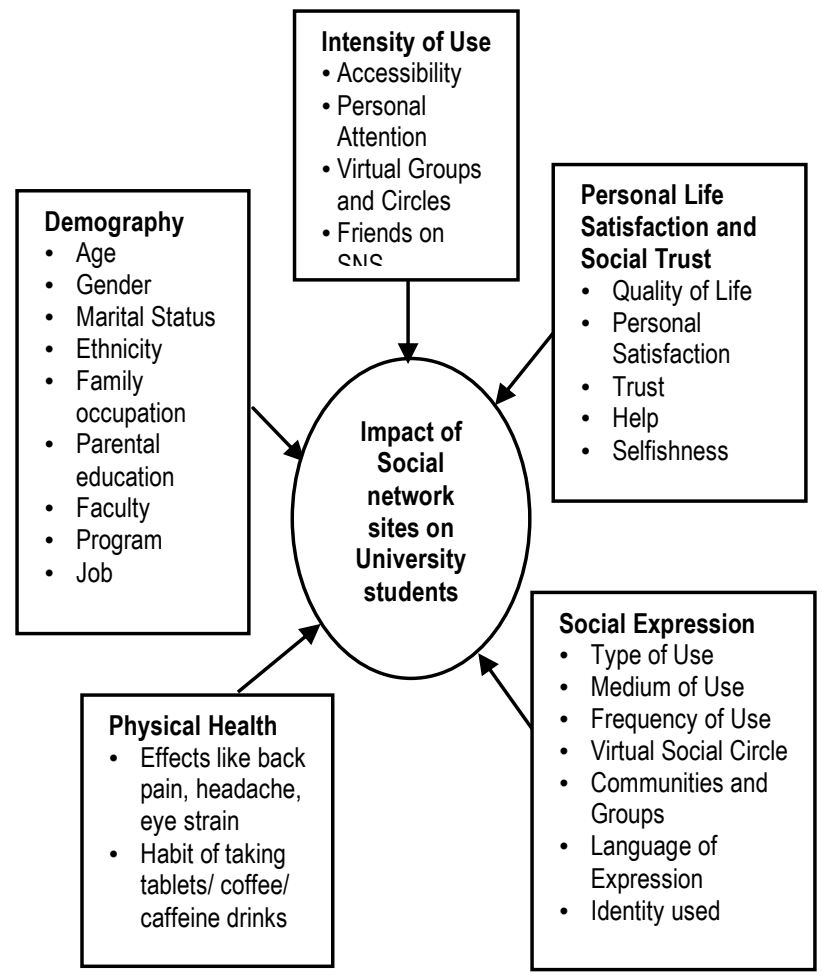

Fig. 3: Conceptual Framework of the study

The fig. 4 below represents the association between Social Network Sites, Intensity of use with demographical data, physical health, personal life satisfaction and social trust. The intensity of use is a very important attribute to study in relation to physical health and find out if this use has created health related problems in individuals. Further, how SNS affect the social trust and personal life satisfaction of individuals with intensity of use. Finally demographic attributes like age, gender, marital status, etc. are also equally important for studying the relationship between SNS and its intensity of use. 


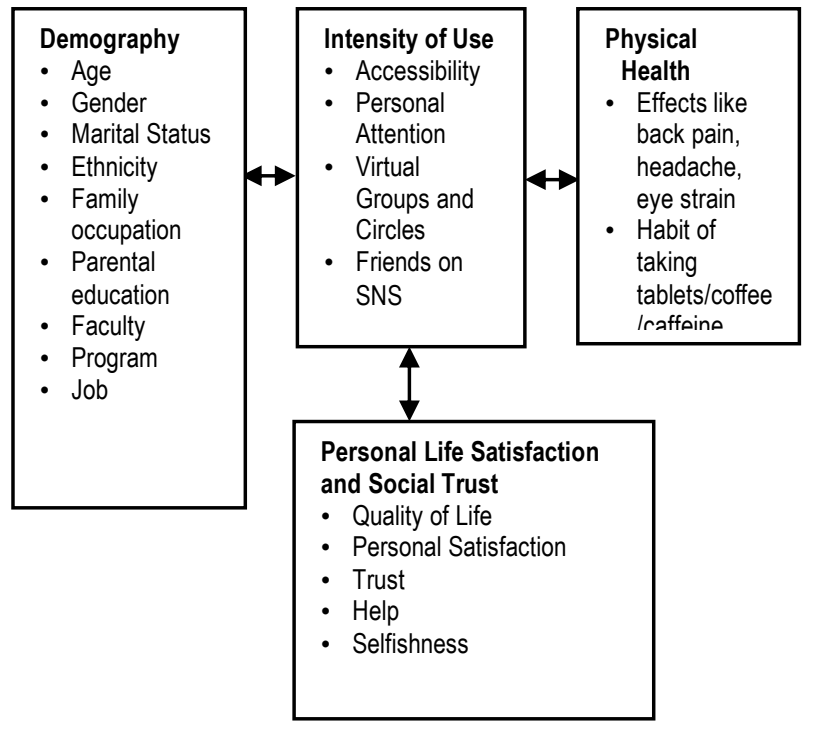

Fig. 4: Representing Association of Intensity of Use with other factors

\section{DATA ANALYSIS AND INTERPRETATION}

This section presents the data analysis and interpretation of the results. It includes different variables of the study which are represented using descriptive statistics and quantitative statistics to understand the impact of the SNS on students of Pokhara University, Nepal.

\section{A. Socio-demographic Characteristics of the Respondents}

Socio-demographic characteristics play an important role in analyzing the impact of the technology on real basis. Our study depicted that the majority of the respondents were males that made $52 \%$ of the population and remaining $48 \%$ were female respondents as shown in figure 5. The age of respondents $(53.9 \%)$ were from the age group 21 to 25 years where as only 46.1 per cent of the respondents were from the age group 15 to 20 years. Most of the respondents $(98.1 \%)$ were not currently employed and only $1.9 \%$ of them were having a part time job.

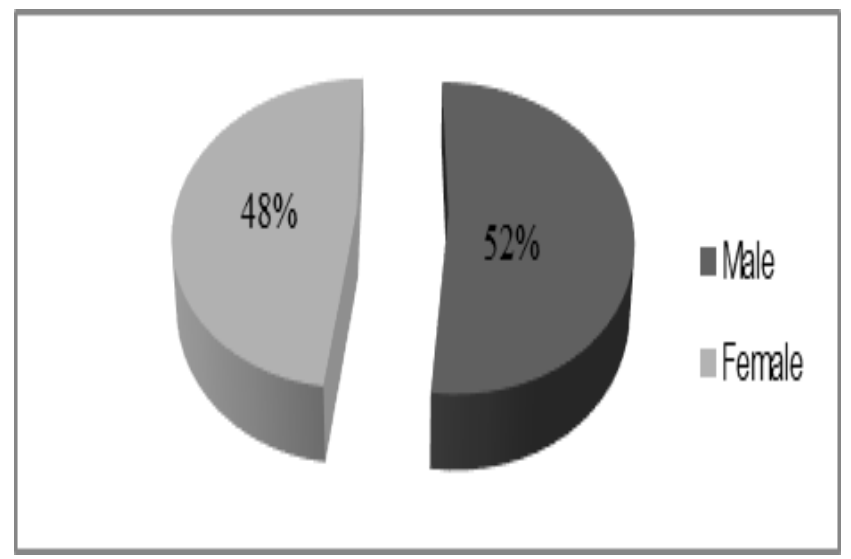

Fig. 5: Gender of the respondents. Source: Field survey 2019

\section{B. Social Sites Expressions}

Social expressions on Social Network Sites portray feeling and emotions through use of media and these activities help to keep up of form relationships. The study revealed that respondents had more friends made on SNS than in real life around $61.7 \%$ while $44.8 \%$ agreed that these friends were also known in their real life as shown in figure 6.

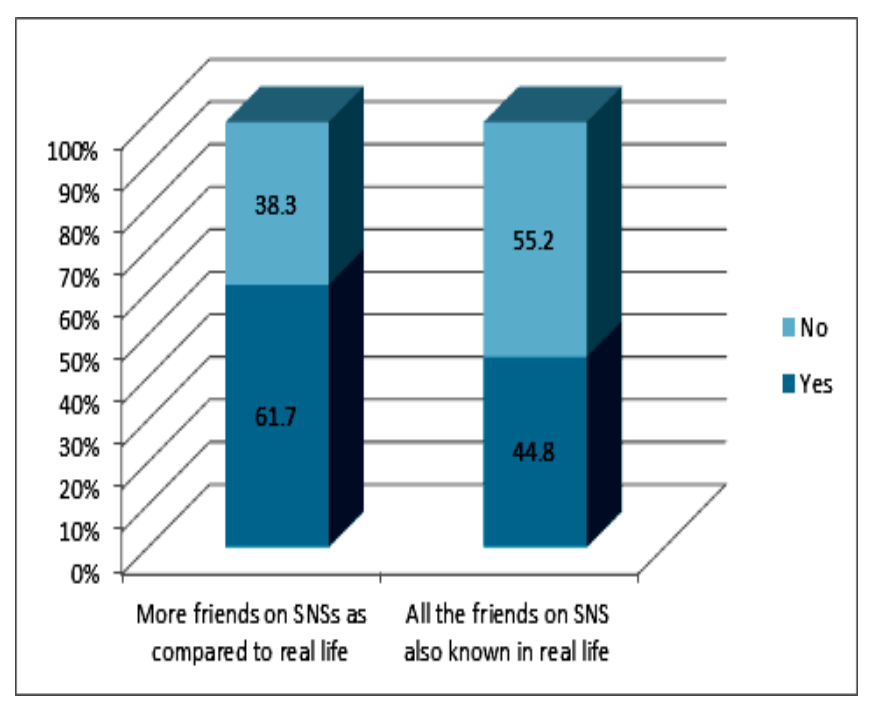

Fig. 6: Relationship representation of respondents, Survey data 2019

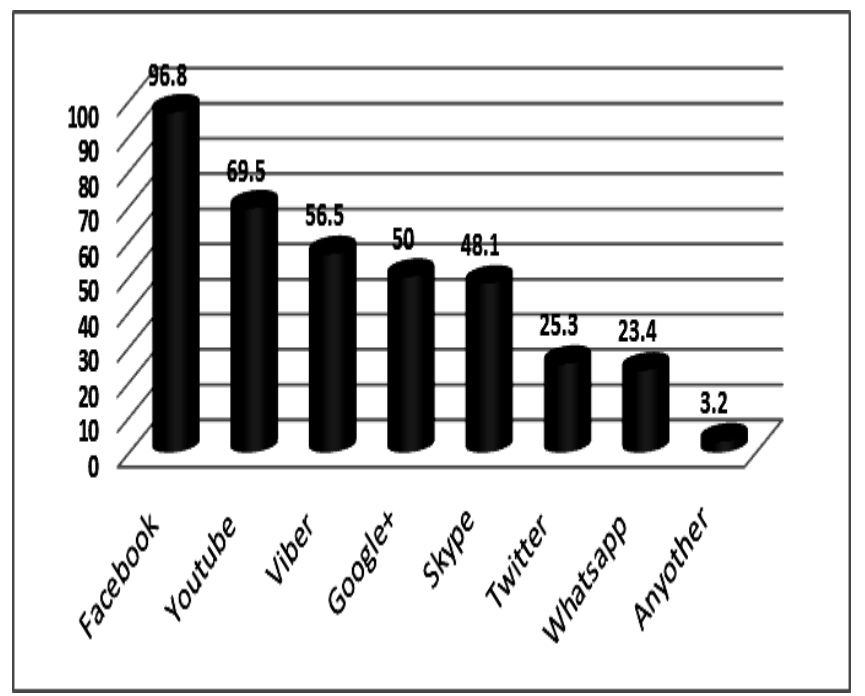

Fig. 7: Affiliation of Social Network Sites of respondents, Survey data 2019

It was seen that $72.1 \%$ of the respondents had SNS affiliation, (72.7\%) preferred to express their ideas and feeling on SNSs and $64.9 \%$ were comfortable about posting related to their personal life, $29.9 \%$ respondents had used fake names and IDs to portray themselves while $70.1 \%$ used their original identity. Further as presented in figure 7, it was noted that $96.8 \%$ of the respondents had a Facebook profile, $69.5 \%$ had a YouTube account, 56.5 were using Viber, 50\% were in Google+ and $48 \%$ were in Skype. Most of the respondents had multiple accounts and they were using all of them effectively. 


\section{Intensity of SNS Use}

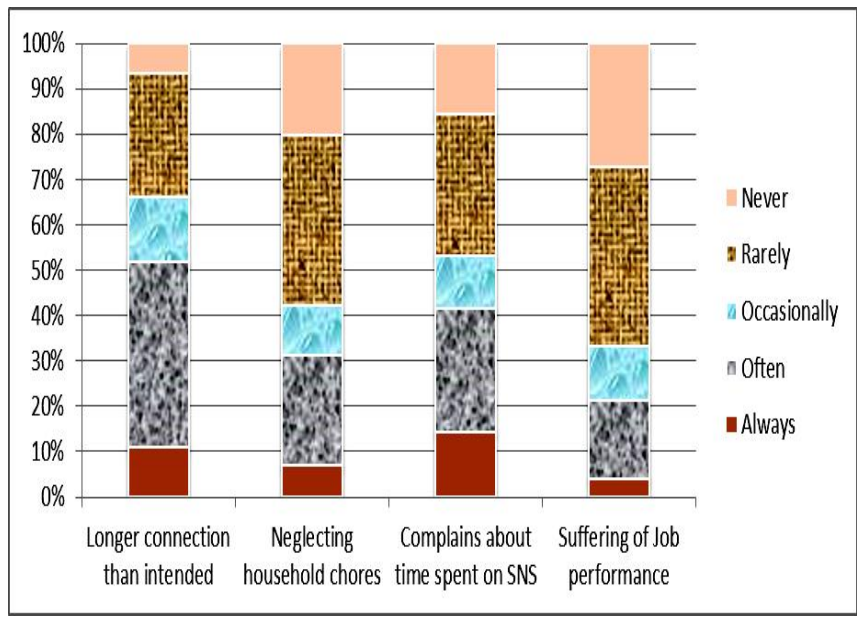

Fig. 8: Representation of intensity of use on Social Network Sites of respondents, : Source field survey 2019

The intensity of use is an important parameter to understand in order to calculate impact and association of other parameters. Figure 8, illustrates that more than $40 \%$ of the total respondents often found that they stayed longer than they had intended online. More than one-third of the total respondents $(38 \%)$ rarely neglected household chores to spend more time connected to SNS. Majority of the respondents (about 40\%) rarely had their job performance or productivity suffered because of the connection to SNS while about 4 per cent always had such problem. It was seen that $29.2 \%$ of the respondents were using the SNS for more than 2 hrs a day, while $20.8 \%$ for at least $2 \mathrm{hrs}$ and $5.8 \%$ were always seen active. It was also interesting to note that one-third of the total $33.8 \%$ of the respondents often checked email and $31.2 \%$ rarely checked emails as represented in figure $9.14 .3 \%$ made new relationships while $44.8 \%$ rarely formed new relationships, $2.7 \%$ were losing sleep due to SNS and around $28.6 \%$ took it as a part of their daily activity as shown in figure 8 .

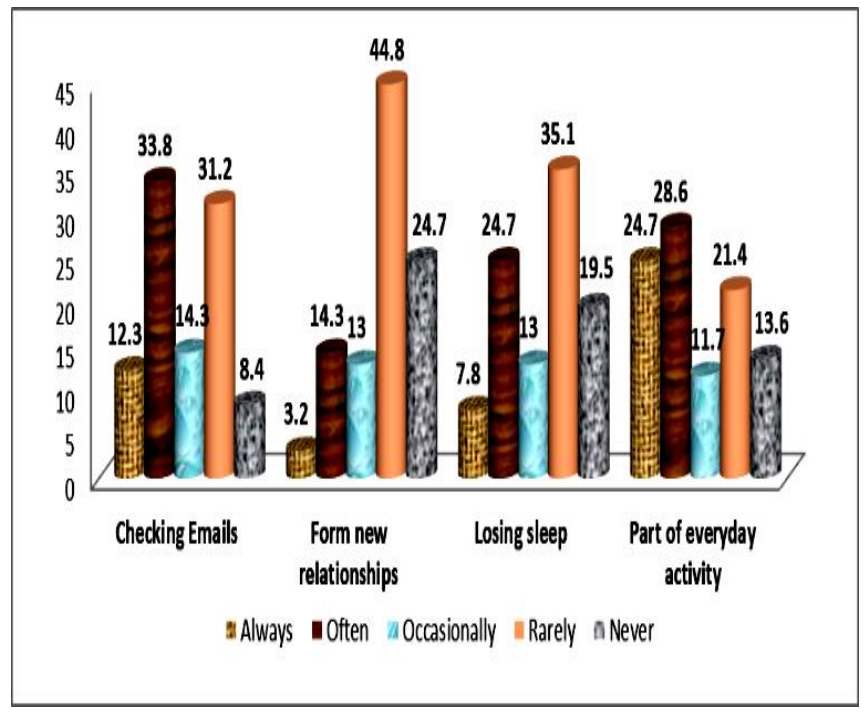

Fig. 9: Representation of usage of Social Network Sites, Source field survey 2019
Further, the study of application of Social network sites for the respondents show that $79 \%$ use for posting photos, $70 \%$ for uploading contents, $69.3 \%$ of the respondent use it for chatting, $63.4 \%$ for communicating with teachers and $30.70 \%$ for downloading as shown in figure 10 . The other variables had less than $10 \%$ of response and hence were discarded for analysis.

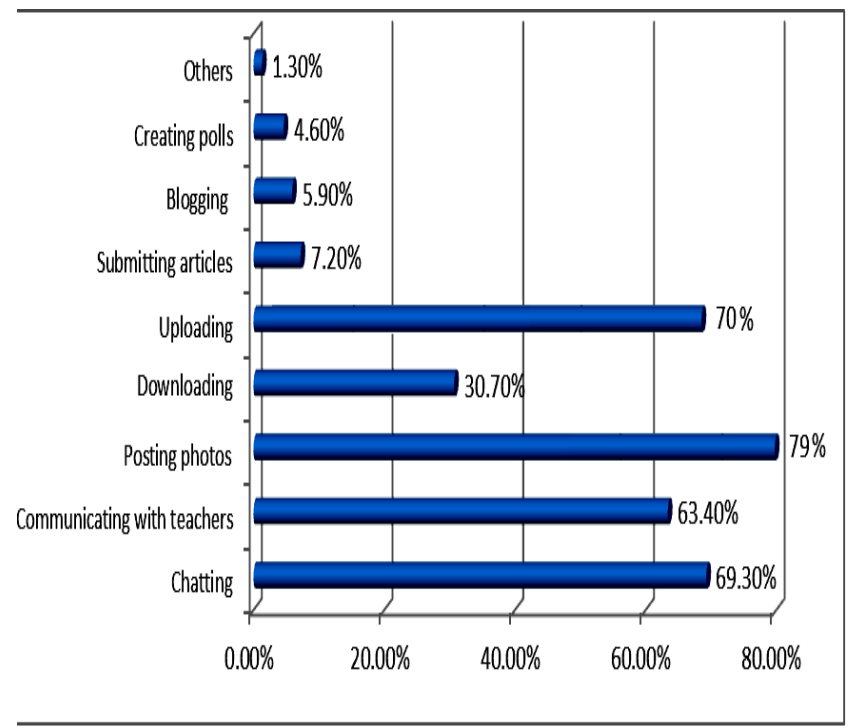

Fig. 10: Representation of different applications of Social Network Sites, Source field survey 2019

\section{SNS Effects on Students Learning}

The popularity and use of SNS has always created a debate between its usefulness and uselessness. The debate of SNS in shaping the learning abilities of student is very important. The table 1 reveals that nearly $63.6 \%$ of the total respondents believed that use of SNS had affected their grades or their school work, 92.2\% thought that it had helped them academically while 51.3 took it as an important tool for communicating and collecting academic material.

Table 1: Impact of SNS on Student learning, Survey data 2019

\begin{tabular}{|l|r|r|}
\hline Variables (n=154) & Frequency & Percentage \\
\hline Use of SNS affects grades or school work & 98 & 63.6 \\
\hline Yes & 56 & 36.4 \\
\hline No & 142 & 92.2 \\
\hline $\begin{array}{l}\text { Social network sites help academically in getting educational materials } \\
\text { for the assignment and project work }\end{array}$ \\
\hline Yes & 12 & 7.8 \\
\hline No & 79 & 51.3 \\
\hline $\begin{array}{l}\text { Social network sites are more effective in communicating with teachers } \\
\text { than in actual class }\end{array}$ \\
\hline Yes
\end{tabular}


Further the majority of the respondents $(93 \%)$ thought that is an effective tool for e-learning, while $7 \%$ did not agree to the role of SNS as an effective tool in learning as shown in figure 11 .

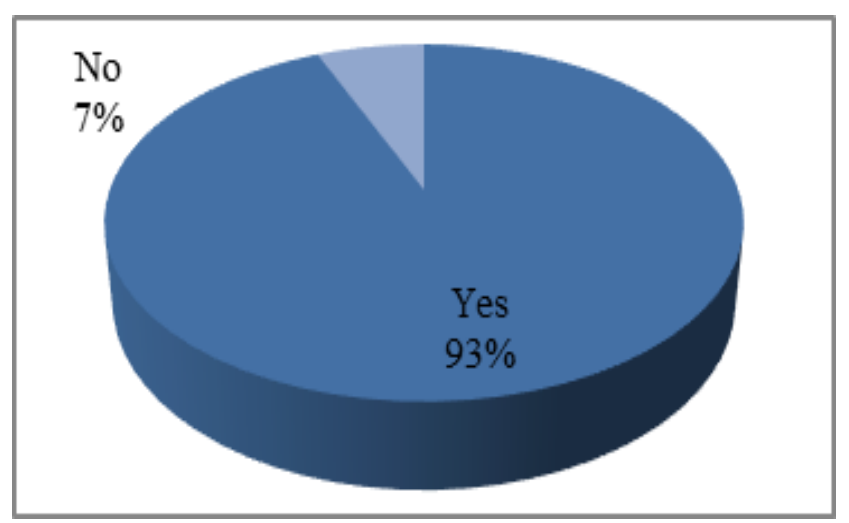

Fig. 11: Representation of Social Network Sites as a tool for learning, Source field survey 2019

The maximum utilization of SNS was seen in entertainment purpose $58.80 \%$ and educational purpose with $52.90 \%$ while $45.80 \%$ used it to get information as illustrated in figure 12 . The data clearly indicated that there is a positive use of Social Network sites on the life of an individual.

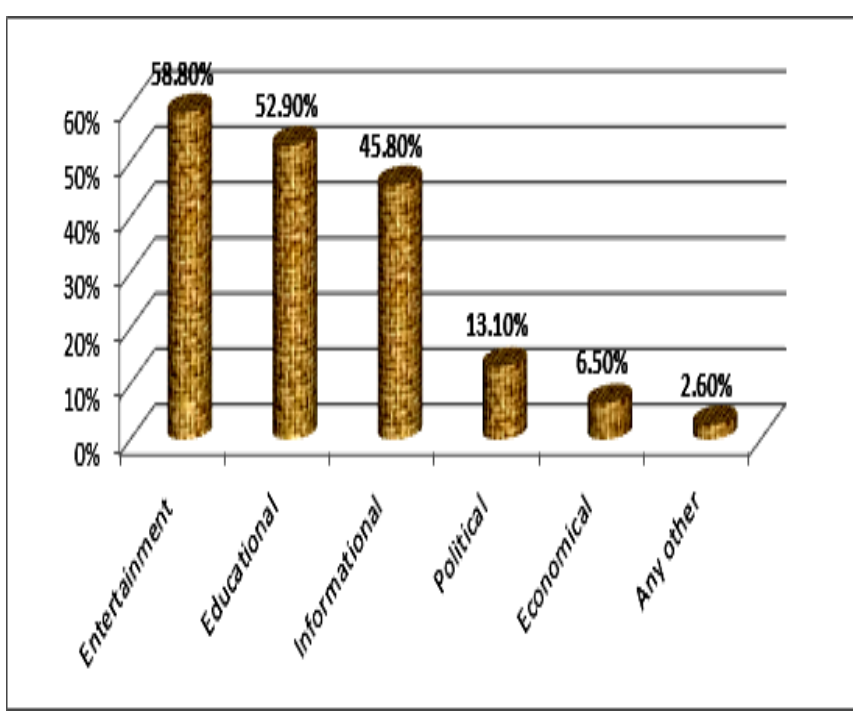

Fig. 12. Representation of purpose of primary use of SNS, Source field survey 2019

\section{E. Effects of SNS on Physical Health}

The effect of SNS on physical health is seen as one of the most important aspect of our study. Data showed that respondents experienced back pain, headaches, eye strain, weight gain or loss and strain on hands/arms. Some even got addicted to taking tablets of caffeine, drinks as well as sleeping pills. The table 2 revealed the impact of SNS on physical health and data depicted that $(74 \%)$ believed that their physical health was affected (e.g., back pain, headaches, eye strain, strain on hands/arms, etc.) and $26 \%$ of the respondents were addicted to tablets, drinks, caffeine to keep them awake. About 5\% of the total respondents were found to take sleeping pills to help them go to sleep after being connected to SNS for an extended period of time.
Table 2: Impact of SNS on Health Status of respondents, Survey data 2019

\begin{tabular}{|l|r|r|}
\hline Variables (n=154) & Frequency & Percentage \\
\hline You believe that your use of SNS affects your physical health \\
\hline Yes & 114 & 74.0 \\
\hline No & 40 & 26.0 \\
\hline $\begin{array}{l}\text { You take tablets/ drink coffee/ drink caffeine drinks while you are } \\
\text { connected to SNS to keep awake and stay online longer }\end{array}$ \\
\hline Yes & 114 & 26.0 \\
\hline No & 40 & 74.0 \\
\hline $\begin{array}{l}\text { After being connected to SNS for an extended period of time, you } \\
\text { take sleeping pills to help you go to sleep }\end{array}$ & 146 & 94.8 \\
\hline Yes & \multicolumn{3}{|c|}{8} \\
\hline No & 146 \\
\hline
\end{tabular}

Figure 13, depict the overall result of the Social network sites on the health of an individual. $77 \%$ of the users reported that they had some minor to major health problems using facebook as a regular medium. The health problems included headache, sleep irregularity, eye strain, ergonomic problems and other minor issues.

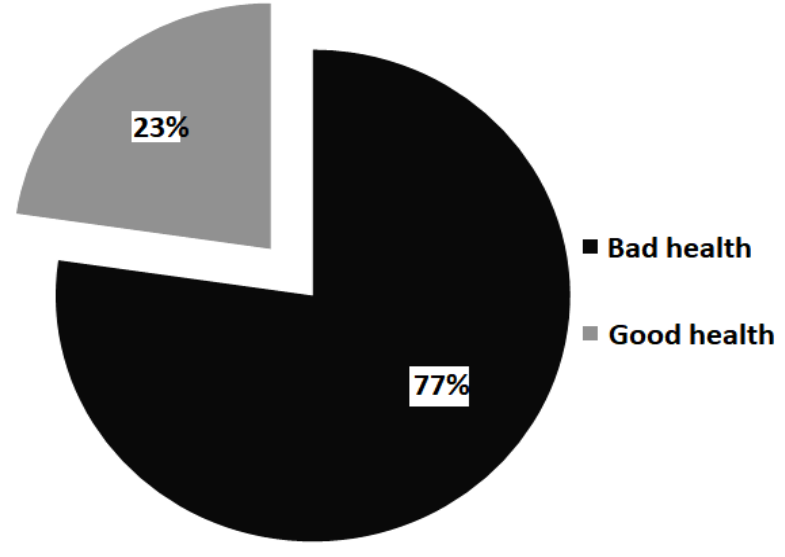

Fig. 13: Representation of health conditions of respondents using SNS, Source field survey 2019

\section{F. Effects of SNS on Personal life satisfaction}

Life satisfaction is the way people show their emotions and feelings on SNS. From the table 3 showing the effect of SNS on personal life satisfaction of 154 respondents, it is seen that more than one-third of them (36.4\%) agree with the statement that in most ways their life was close to their ideal while nearly equal percentage of them (34.4\%) remained neutral for the statement. More than 42 per cent of the total respondents remained neutral to the statement that the conditions of their life are excellent whereas nearly 38 per cent were agreed to the statement.Nearly half of the total respondents were agreed and even nearly 20 per cent were strongly agreed to that they were satisfied with their life whereas about 24 per cent remained neutral. About 40 per cent of 154 respondents were agreed that they had so far got the important things they wanted in life whereas about 31 per cent remained neutral. One-third of the total respondents disagreed, 24 per cent agreed and about 25 per cent remained neutral to the statement that if they could 
have lived their life over, they would have had changed almost nothing.

Table 3: Effects of SNS on Personal life satisfaction, Source field survey 2019

\begin{tabular}{|c|c|c|}
\hline Variables $(n=154)$ & Frequency & Percentage \\
\hline \multicolumn{3}{|c|}{ In most ways my life is close to my ideal } \\
\hline Strongly agree & 4 & 2.6 \\
\hline Agree & 56 & 36.4 \\
\hline Neutral & 53 & 34.4 \\
\hline Disagree & 30 & 19.5 \\
\hline Strongly disagree & 11 & 7.1 \\
\hline \multicolumn{3}{|c|}{ The conditions of my life are excellent. } \\
\hline Strongly agree & 11 & 7.1 \\
\hline Agree & 58 & 37.7 \\
\hline Neutral & 65 & 42.2 \\
\hline Disagree & 16 & 10.4 \\
\hline Strongly disagree & 4 & 2.6 \\
\hline \multicolumn{3}{|c|}{ I am satisfied with my life. } \\
\hline Strongly agree & 30 & 19.5 \\
\hline Agree & 75 & 48.7 \\
\hline Neutral & 36 & 23.4 \\
\hline Disagree & 10 & 6.5 \\
\hline Strongly disagree & 3 & 1.9 \\
\hline \multicolumn{3}{|c|}{ So far I have gotten the important things I want in life. } \\
\hline Strongly agree & 9 & 5.8 \\
\hline Agree & 61 & 39.6 \\
\hline Neutral & 48 & 31.2 \\
\hline Disagree & 27 & 17.5 \\
\hline Strongly disagree & 9 & 5.8 \\
\hline \multicolumn{3}{|c|}{ If I could live my life over, I would change almost nothing. } \\
\hline Strongly agree & 11 & 7.1 \\
\hline Agree & 37 & 24.0 \\
\hline Neutral & 39 & 25.3 \\
\hline Disagree & 51 & 33.1 \\
\hline Strongly disagree & 16 & 10.4 \\
\hline
\end{tabular}

From the figure 14, life satisfaction level of 154 respondents from Social network site can be seen. The data shows that more than half of the total respondents were satisfied with their life and nearly 5 per cent were extremely satisfied whereas one-fourth of the total respondents were dissatisfied and only 0.6 per cent were extremely dissatisfied but about 10 per cent felt neither satisfied nor dissatisfied with their life.

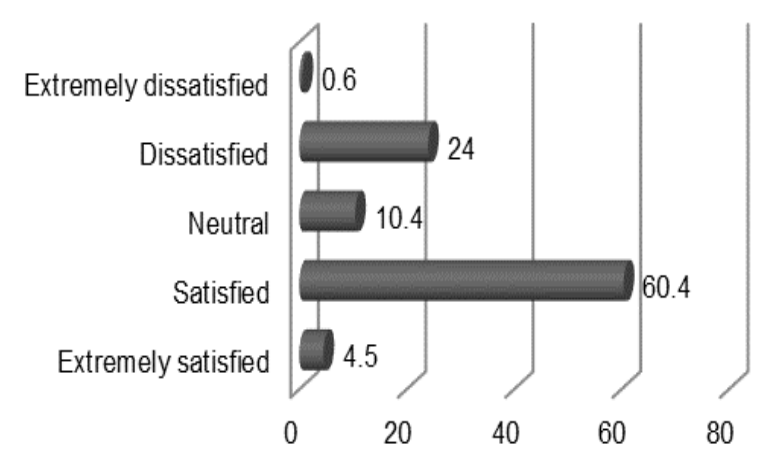

Fig. 14: Life satisfaction level of the respondents. Source field survey 2019

\section{G. Effects of SNS on Social Trust}

Table 4: Impact of SNS on Social trust of respondents, Source field survey 2019

\begin{tabular}{|l|r|r|}
\hline Variables (n=154) & Frequency & Percentage \\
\hline Generally speaking, people can be trusted & 4 & 2.6 \\
\hline all of the time & 10 & 6.5 \\
\hline most of the time & 79 & 51.3 \\
\hline some of the time & 79 & \\
\hline
\end{tabular}

People try to take advantage of you if they got the chance (reversed)

\begin{tabular}{|l|r|r|}
\hline all of the time & 25 & 16.2 \\
\hline most of the time & 46 & 29.9 \\
\hline some of the time & 58 & 37.7 \\
\hline People try to be fair (ie, try to look good) & 37 & 24.0 \\
\hline all of the time & 62 & 40.3 \\
\hline most of the time & 35 & 22.7 \\
\hline some of the time & & \\
\hline
\end{tabular}

Social trust defines the confidence of individuals to publish their feelings and expressions on SNS. The survey revealed that more than half of them $(51.3 \%)$ agreed that people could be trusted while 26 per cent found hard to trust people as shown in table 4. More than one-third of the respondents agreed to the statement that people try to take advantage whereas about 16 per cent told that people take advantage all of the time. About $40 \%$ of the total respondents declared that people try to be fair most of the time, 24 per cent said the situation remains all of the time and nearly 23 per cent said it is only sometime. Nearly half of the respondents (49\%) agreed to that they couldn't be too careful in dealing with people whereas about 7 per cent were not careful all of the time. More than half of the total respondents $(54 \%)$ said that people tried to be helpful only sometimes whereas about $4 \%$ gave negative views that people never tried to be helpful. From figure 15, it is seen that nearly two-third of them $(64.3 \%)$ were having high level of social trust whereas least $(2.6 \%)$ of them were having very high level of it. 


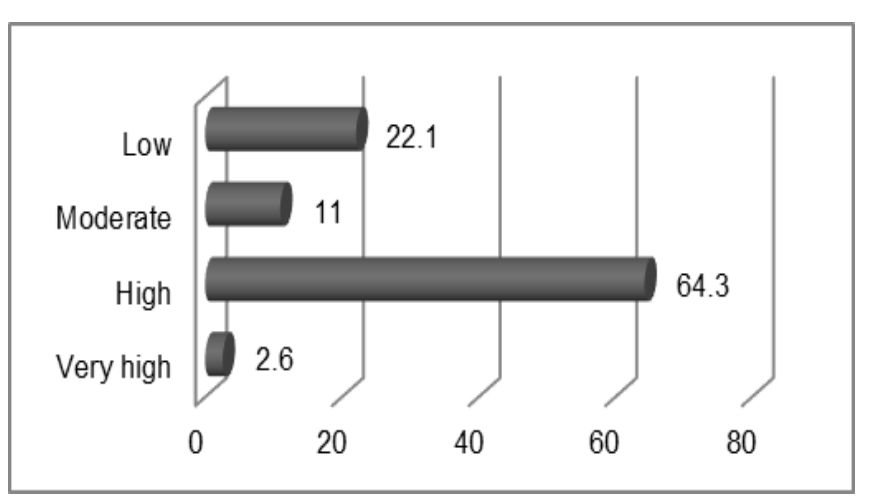

Fig. 15: Representation of social trust of respondents using SNS, Source field survey 2019

As shown in table 5, the descriptive statistics states that the mean of total SNS friends of the respondents is about 373 having the standard error of 23.494 and having the minimum no. as 38 and maximum no. as 2000. Similarly, it can be seen that the mean of no. of joined groups of the respondents is 7.56 having the standard error of 0.482 , standard deviation of 5.9, variance of 35.8 and having the minimum no. as 0 and maximum as well as range no. as 36 . Besides it is clearly seen that the mean values of life satisfaction level (0.6104) and social trust level (0.6185) are higher than that of physical health level (0.2273). The mean value of SNS intensity level is 2.3701 which is a little more than moderate level.

Table 5: Descriptive Statistics of respondents, Source field survey 2019

\begin{tabular}{|l|c|c|c|c|c|c|}
\hline & $\begin{array}{c}\text { Total } \\
\text { SNS } \\
\text { friends }\end{array}$ & $\begin{array}{c}\text { No. of } \\
\text { joined } \\
\text { Groups }\end{array}$ & $\begin{array}{c}\text { Physical } \\
\text { health } \\
\text { level }\end{array}$ & $\begin{array}{c}\text { Life } \\
\text { satisfaction } \\
\text { level }\end{array}$ & $\begin{array}{c}\text { Social } \\
\text { trust } \\
\text { level }\end{array}$ & $\begin{array}{c}\text { SNS } \\
\text { intensity } \\
\text { level }\end{array}$ \\
\hline Mean & 373.27 & 7.56 & 0.2273 & 0.6104 & 0.6185 & 2.3701 \\
\hline $\begin{array}{l}\text { Std. Error } \\
\text { of Mean }\end{array}$ & 23.494 & 0.482 & 0.03388 & 0.01871 & 0.01742 & 0.05447 \\
\hline $\begin{array}{l}\text { Std. } \\
\text { Deviation }\end{array}$ & 291.559 & 5.985 & 0.42044 & 0.23219 & 0.21617 & 0.67593 \\
\hline Variance & 8.5014 & 35.817 & 0.177 & 0.054 & 0.047 & 0.457 \\
\hline Range & 1962 & 36 & 1.00 & 1.00 & 0.75 & 3.00 \\
\hline Minimum & 38 & 0 & 0.00 & 0.00 & 0.25 & 1.00 \\
\hline Maximum & 2000 & 36 & 1.00 & 1.00 & 1.00 & 4.00 \\
\hline
\end{tabular}

\section{CONCLUSION}

The study concludes that majority of the students were spending more than two hours per day on social network sites and nearly all respondents were improving their knowledge about a product, service or organization and expressing their ideas and feelings. This proves that SNSs are being used as a platform for expressions of their thoughts and feelings. The personal life quotient was found to be rich as most of the respondents made new relationships, got entertained and educated themselves from the Social Network Sites. The majority of the respondents trusted the communication in SNS and a majority of them used it as a space to express themselves. Social trust was seen high and indicated a positive growth in the coming days. The study showed positive repercussion of participation in SNS in the personal development in terms of self-esteem and psychological well-being. A majority of the respondents showed low physical health level and an association between physical health level and SNS intensity level at 1 percent of significance. Though SNS were primarily used for chatting by more than two-third of the total respondents, nearly twothird used it for communication with teachers and class fellows. The findings conclude that majority of the respondents were having positive effects of SNS in their learning performance and also had a thought that SNSs can be an effective tool for e-learning specially for understanding assignments. Overall, positive impact is seen in the life of university students, through the use of Social Network Sites of Pokhara University, Nepal.

\section{RECOMMENDATIONS}

On the basis of above findings of this study it is recommended that awareness programs should be launched to make users aware about negative impacts of SNSs like health impacts, Facebook Addiction Disorder (FAD) and the risk of addiction. Further studies including broader health impacts like depression and anxiety should be conducted. Policies have to be devised in such a way by governments, academic institutions and civil authorities to maximize the benefits of Social Network Sites.

\section{CONFLICTS OF INTEREST}

The authors have no conflicts of interest to declare. The authors confirm that we have no affiliation with any organization with a direct or indirect financial interest in the subject matter discussed in the manuscript.

\section{ACKNOWLEDGMENT}

This work would like to acknowledge Pokhara University and its constituent campuses to allow students to participate in this survey.

\section{REFERENCES}

[1] Okunna, S.C., Introduction to mass communication. Enugu: New Generation Books, National Open University of Nigeria, First Printed 2012, ISBN: 978-058-779-9.

[2] Ross, C., Orr, E. S., Sisic, M., Arseneault, J. M., Simmering, M. G., and Orr, R., "Personality and motivations associated with Facebook use. Computers In Human Behavior", 25(2), 578-586. doi:10.1016/j.chb.2008.12.024.

[3] Zizi Papacharissi.,"A Networked Self: Identity, Community, and Culture on Social Network Sites", New York, Routledge Taylor \& Francis Groupxelrod, New York: Basic Books, 2011.

[4] Facebook. "Facebook.com Statistics", Retrieved from http://www.facebook.com/press/info.php?statistics, 2011.

[5] Wenjing Xie, Kavita Karan, Predicting Facebook addiction and state anxiety without Facebook by gender, trait anxiety, Facebook intensity, and different Facebook activities, Journal of Behavioral Addictions, Volume 8: Issue 1, Pages: 79-87, 01 Mar 2019, DOI: https://doi.org/10.1556/2006.8.2019.09.

[6] Lewis, S. "Where young adults intend to get news in five years", Newspaper Research Journal, 36-52, Vol. 29, No. 4 , Fall 2008. 
[7] Pempek, et al., 'College students' social networking experiences on Facebook", Journal of Applied Developmental Psychology, 30, 227-238.

[8] Akbiyik, C. "Effects of Social Networks on Social Life of Undergraduate Students", Middle Eastern \& African Journal of Educational Research, 4(6), pp. 4-10, 2013.

[9] Hyllegard, K. H., Ogle, J. P., Yan, R., and Reitz, A. R. "An exploratory study of college students' fanning behavior on Facebook", College Student Journal, 45(3), 601-616. Retrieved October 16, 2014.

[10] Jomon, A.P., Hope, M.B. and Justin, D.C, "Effect of online social networking on student academic performance," Computers in Human Behavior, Elsevier Ltd, USA, pp. 21172127, 2012.

[11] Ikord, J. "Understanding the Face book generation: a study of the relationship between online social networking and academic and social integration and intentions to re-enroll." ProQuest Information and Learning Company, 2008.

[12] Kist, W., "I gave up myspace for lent: New teachers and social network sites" Retrieved at http://www.michelepolak.com/200fall10/Weekly_Schedule_f iles/Kist.pdf.

[13] Ansari, J.A.N., Khan, N.A. Exploring the role of social media in collaborative learning the new domain of learning. Smart Learn. Environ. 7, 9 (2020). https://doi.org/10.1186/s40561020-00118-7

[14] Das, B., Sahoo, J. "Social network sites: a critical analysis of its impact on personal and social life", International Journal of Business \& Social Science, 2(14), 222-228, 2011

[15] Danah m. Boyd, Nicole B. Ellison, Social Network Sites: Definition, History, and Scholarship, Journal of ComputerMediated Communication, Volume 13, Issue 1, 1 October 2007, Pages 210-230, https://doi.org/10.1111/j.10836101.2007.00393.x

[16] Boyd, D.M., and Ellison, N.B. "Social network sites: Definition, history, and scholarship", Journal of ComputerMediated Communication, 13, 210-230, 2007.

[17] Emeri, Patience Nnenne, INFLUENCE OF SOCIAL MEDIA ON STUDENTS' ACADEMIC PERFORMANCE IN LAGOS METROPOLIS, International Journal of Educational, Department of Educational Foundations (with Educational Psychology), University of Lagos, Research Vol. 6, No 1, 2019, eISSN: 1595-8485.

[18] Khondokar Humayun Kabir, Debashis Roy, M. Abul Kashem. Social Computing Behavior of the Students of Bangladesh Agricultural University, Mymensingh. Social Sciences. Vol. 5, No. 6, 2016, pp. 86-93. doi: 10.11648/j.ss.20160506.12

[19] M. Owusu Acheaw, Agatha Gifty Larson, Use of Social Media and its Impact on Academic Performance of Tertiary Institution Students: A Study of Students of Koforidua

[20] Polytechnic, Ghana, Journal of Education and Practice, ISSN 2222-1735 (Paper) ISSN 2222-288X (Online), Vol.6, No.6, 2015.

[21] Osita Ejikeme, Uzoma Ebubechukwu, Social Media and Students' Academic Performance among Secondary School Students, International Journal of Researche, ISSN: 23486848, p-ISSN: 2348-795X, Volume 05 Issue 19, August 2018, Available at https://edupediapublications.org/journals.

[22] Shah, D.V., "Civic engagement, interpersonal trust, and television use: An individual-level assessment of social capital", Political Psychology, 19(3), 469-496, 1998.

[23] Procentese F, Gatti F, Di Napoli I. Families and Social Media Use: The Role of Parents' Perceptions about Social Media Impact on Family Systems in the Relationship between
Family Collective Efficacy and Open Communication. Int $\mathbf{J}$ Environ Res Public Health. 2019;16(24):5006. Published 2019 Dec 9. doi:10.3390/ijerph16245006.

[24] Shaohai Jiang, Annabel Ngien, The Effects of Instagram Use, Social Comparison, and Self-Esteem on Social Anxiety: A Survey Study in Singapore, Social Media + Society, Sage publications, April 1, 2020, Volume: 6 issue: 2, DOI: $10.1177 / 2056305120912488$

[25] Editorial Statista, Most popular social networks data of January 2021, ranked by number of active users(in millions), Internet Social Media \& User-Generated Content, Statista GmbH, Johannes-Brahms-Platz 1, 20355 Hamburg, Germany

[26] Marie Ozanne, Ana Cueva Navas, Anna S. Mattila, and Hubert B. Van Hoof, An Investigation Into Facebook "Liking" Behavior An Exploratory Study, Social Media Plus Society, April-June 2017: 1-12, 2017, Sagepub Publications, UK, DOI: $10.1177 / 2056305117706785$.

\section{ABOUT THE AUTHORS}

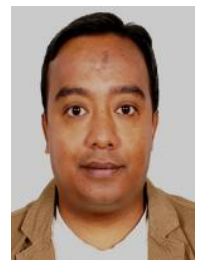

Deepanjal Shrestha is a $\mathrm{PhD}$ Scholar at Nanjing University of Aeronautics and Astronautics, School of Computer Science and Technology, Nanjing, China. He is also an Assistant Professor of MIS at Pokhara University, School of Business, Nepal. His research area include MIS, Software Engineering, and Digital Ecosystems.

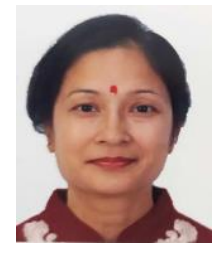

Neesha Rajkarnikar is a $\mathrm{PhD}$ Scholar at Nanjing Tech University, Department of New Energy Science \& Engineering, Nanjing, China. She has a Master's degree in Computer Applications, Masters in Gender \& Development. Her area of interest include Computer Applications, Energy Science \& Social Computing.

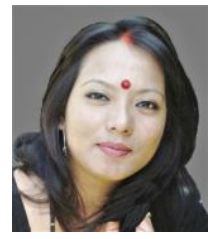

Deepmala Shrestha is a $\mathrm{PhD}$ candidate at Pokhara University School of Management, Nepal. She is also an Assistant Professor in School of Business, Pokhara University. She holds an MBA and MPhil degree in Management. Her research interest includes HRM and General Management.

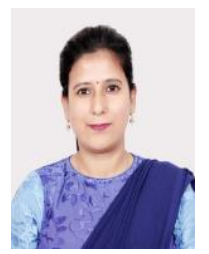

Rojana Dhakal is an Assistant Professor of Nursing at School of Health and Allied Sciences, Pokhara University, Nepal. She holds an MSc Nursing degree from Rajiv Gandhi University of Health Sciences, India. Her research interest include maternal health nursing, breast cancer, women's health issues, nursing education.

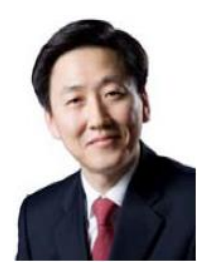

Seung Ryul Jeong is a Professor at Graduate School of Business IT, Kookmin Univ., Korea. He holds a Ph.D. in MIS from Univ. of South Carolina, SC, U.S.A. His research interest include: MIS, e-Business, System Implementation, Process Innovation, Text Mining, Project Management, Information Resource Management, etc. 